\section{Biosolids Promote Similar Plant Growth and Quality Responses as Conventional and Slow-release Fertilizers}

\author{
Shaun R. Broderick ${ }^{1}$ and Williams B. Evans
}

ADDITIONAL INDEX WORDs. petunia, swiss chard, kale, dianthus, nutrient, sewage

SUMMARY. Biosolids are rich in plant nutrients and are a byproduct of municipal wastewater treatment and those that meet strict government safety standards can be land applied in most agricultural settings except for the U.S. Department of Agriculture (USDA) certified organic production. Across the United States, about $60 \%$ of biosolids are land applied, but in Mississippi almost no biosolids are land applied. Our research goal was to compare plant size in southeastern U.S. soils amended with biosolids at rates of $2,8,14$, and 20 tons/acre in contrast to soils amended with synthetic fertilizers using 'Floral Lace Cherry' dianthus (Dianthus chinensis $\times$ barbatus), 'Dreams Coral Morn' petunia $($ Petunia $\times$ bybrida), 'Pidgeon White' kale (Brassica olevaceae var. acephala), and 'Bright Lights' swiss chard (Beta vulgaris ssp. cicla). To accomplish this, fertilizers and biosolids were applied to prebedded fields in a randomized complete block design with a split-plot arrangement of nutrient treatments. Plant performance data and soil data were taken $\mathbf{4 3}$ and 56 days after transplant. Soil $\mathrm{pH}$ was reduced and organic matter increased at the highest application rates (14 and 20 tons/acre) of biosolids, and higher levels of phosphorus, zinc, and sulfur were found in these soils. In plant shoots, higher levels of copper, manganese, magnesium, and zinc were found when grown in soils amended with biosolids at a rate of 20 tons/acre compared with plants grown with synthetic fertilizers. Except for swiss chard, no crops fertilized with biosolids exhibited a difference in dry weights (DW) compared with conventional fertilizers. These data demonstrate that soil properties can be improved and similar plant sizes can be achieved through biosolid applications. We conclude that Grade A biosolids produced in Mississippi can be used to supplement synthetic fertilizers for ornamental and vegetable production.

W Tastewater disposal can be challenging for municipalities. Before the 1950s, wastewater was disposed of in bays, lakes, and rivers, which resulted in high levels of pollution [U.S. Environmental Protection Agency (USEPA), 1979]. In response to government regulations, alternative methods of processing and using municipal sewage have been developed. Specifically, methods have been developed to process sewage sludge from municipalities into a soil amendment, termed "biosolids." The

Mississippi Agriculture and Forestry Experiment Station, Mississippi State University, Truck Crops Branch Experiment Station, 2024 Experiment Station Road, Crystal Springs, MS 39059.

This publication is a contribution of the Mississippi Agricultural and Forestry Experiment Station. This material is based upon work that is supported by the National Institute of Food and Agriculture, U.S. Department of Agriculture, Hatch project under accession numbers 0209485 and 1006346.

We thank the Clinton (Mississippi) Public Works Department for supplying the biosolids for this research. We also thank Richard G. Snyder and Bisoondat Macoon for reviewing the article.

${ }^{1}$ Corresponding author. E-mail: srb559@msstate. edu.

doi: 10.21273/HORTTECH03639-17 quality of the biosolids varies among municipalities because of incoming sewage, runoff water quality, and processing methods. Therefore, biosolids are graded based on strict safety requirements established by the USEPA in the 1970s. Regulated characteristics include pathogen content, the extent to which it attracts vectors (e.g., birds, insects, rodents, etc.), and the concentration of trace elements [e.g., arsenic (As), cadmium $(\mathrm{Cd})$, copper $(\mathrm{Cu})$, lead $(\mathrm{Pb})$, mercury $(\mathrm{Hg})$, etc.], and nutrients. USEPA Grade A, exceptional quality (EQ) biosolids exceed all of these safety requirements and are cleared for most agricultural applications including use on edible crops with exception of all USDAcertified organic production. Grade B biosolids do not meet all of the safety requirements and are restricted in their use and access by the general public ( $\mathrm{Lu}$ et al., 2012; USEPA, 1995).

Biosolids can be a valuable source of plant nutrients. In contrast with most conventional fertilizers, biosolids typically have lower levels of nitrogen $(\mathrm{N})$, phosphorus $(\mathrm{P})$, and potassium $(\mathrm{K})$, but supply organic matter and micronutrients, such as boron, magnesium $(\mathrm{Mg}), \mathrm{Cu}$, and zinc $(\mathrm{Zn})$ (Warman and Termeer, 2005). The ratio of $\mathrm{N}$ to $\mathrm{P}$ tends to be lower in composted biosolids because $\approx 15 \%$ of $\mathrm{N}$ is lost during the composting process through ammonia volatilization (Tubail et al., 2008). The application rate of biosolids is often limited by the concentration of $\mathrm{P}$ in the soils. Similar to land application of manures, repeated application of biosolids may result in soil $\mathrm{P}$ concentrations that exceed plant requirements ( $\mathrm{Lu}$ et al., 2012). In addition, agricultural soil with excessive phosphorus can lead to $\mathrm{P}$ contamination of surface waters (Sharpley et al., 1993).

In the United States, $\approx 60 \%$ of biosolids are land applied, but less than $0.1 \%$ of agricultural lands are treated with biosolids annually $(\mathrm{Na}-$ tional Research Council, 2002; North East Biosolids and Residuals Association, 2007). About $40 \%$ of biosolids are typically disposed of in landfills. Almost no biosolids are land applied in the state of Mississippi, despite its potential use in agricultural, forestry, and horticultural landscapes. Two municipalities in Mississippi use a unique European system to produce Grade A, EQ biosolids (P. Fisher, personal communication). This is accomplished by placing pressed, dewatered, sewage solids into an enclosed greenhouse where the biosolids are aerobically

\begin{tabular}{llll}
\hline $\begin{array}{l}\text { Units } \\
\text { To convert U.S. to SI, } \\
\text { multiply by }\end{array}$ & U.S. unit & SI unit & $\begin{array}{l}\text { To convert SI to U.S., } \\
\text { multiply by }\end{array}$ \\
\hline 0.3048 & $\mathrm{ft}$ & $\mathrm{m}$ & 3.2808 \\
3.7854 & $\mathrm{gal}$ & $\mathrm{L}$ & 0.2642 \\
2.54 & inch(es) & $\mathrm{cm}$ & 0.3937 \\
1.1209 & $\mathrm{lb} / \mathrm{acre}$ & $\mathrm{kg} \cdot \mathrm{ha}^{-1}$ & 0.8922 \\
28.3495 & $\mathrm{Oz}$ & $\mathrm{g}$ & 0.0353 \\
1 & $\mathrm{ppm}$ & $\mathrm{mg} \cdot \mathrm{kg}^{-1}$ & 1 \\
2.2417 & $\mathrm{ton}(\mathrm{s}) / \mathrm{acre}$ & $\mathrm{Mg} \cdot \mathrm{ha}^{-1}$ & 0.4461 \\
$\left({ }^{\circ} \mathrm{F}-32\right) \div 1.8$ & ${ }^{\circ} \mathrm{F}$ & ${ }^{\circ} \mathrm{C}$ & $\left({ }^{\circ} \mathrm{C} \times 1.8\right)+32$ \\
& & &
\end{tabular}

Hortlechnology • December 2017 27(6) 
digested under hot and humid conditions. Autonomous tillers continually turn the biosolids until the desired moisture content is achieved. At that point, the biosolids are removed from the greenhouse and tested for quality and contaminants. Although this soil amendment has been made available to the public for pick up, most of it has been disposed of at the landfill. Awareness of this product could increase demand, but the effects of biosolids from these municipalities on soil fertility in this region and on plant size have not been tested. The goal of this research is to measure the effectiveness of these biosolids as a fertilizer and soil amendment and compare their performance with conventional and slow-release fertilizers.

\section{Materials and methods}

Grade A, EQ biosolids were obtained from the City of Clinton (Mississippi) Department of Public Works in Sept. 2015. The biosolids were produced by pressing water out of the sewage sludge. These dewatered solids were spread $\approx 12$ inches deep in an enclosed, ventilated greenhouse where they were dried to a moisture content below 10\% using an autonomous tilling system (Thermo-System Electric Moles ${ }^{\circledR}$; Parkson Co., Fort Lauderdale, FL), which continuously turned the biosolids during the drying process. The stirring and drying process killed remaining pathogens and increased the nutrient and organic matter concentration in the biosolids. After processing, the biosolids were removed to a nearby field and tested for contaminants, nutrient content, and assigned a grade by the Mississippi Department of Environmental Quality (MDEQ) in accordance with USEPA guidelines (USEPA, 1995). The city has a Beneficial Use Determination issued by MDEQ permitting the land application of their EQ processed municipal waste sludge/biosolids.

Field EXPERIMENT DESIGN. To determine the effects of these biosolids on soil and plant size, we amended prebedded field rows with four rates of biosolids: 2, 8, 14, and 20 tons/acre (as delivered wet-weight). In addition, we included comparison plots with either $15 \mathrm{~N}-3.9 \mathrm{P}-10.0 \mathrm{~K}$ slow-release fertilizer $\left(\right.$ Osmocote ${ }^{\circledR}$; Scotts Miracle-Gro, Marysville, $\mathrm{OH}$ )

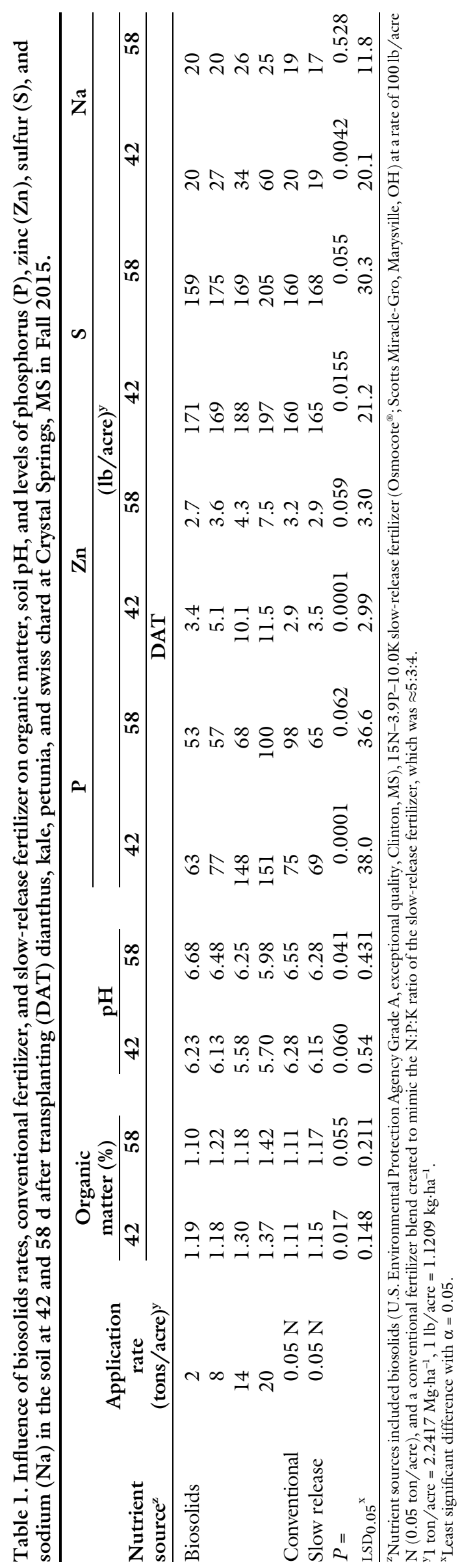


or a conventional fertilizer blend as our experimental controls. Both conventional and slow-release fertilizers were applied at $100 \mathrm{lb} /$ acre $\mathrm{N}$. The conventional fertilizer blend was created to mimic the reported $\mathrm{N}-\mathrm{P}-\mathrm{K}$ ratio of the slow-release fertilizer, which was $\approx 5: 3: 4$. Thus, similar quantities of $\mathrm{P}$ and $\mathrm{K}$ were applied in both the conventional and slow-release fertilizer plots. The field was set up in a randomized complete block design with a split-plot arrangement with the six nutrient applications (four biosolids rates and two conventional fertilizers) serving as the first factor and dianthus, kale, petunia, and swiss chard acting as the second.

The field was prebedded into 6-inch-high by 24-inch-wide rows. Each row was spaced $6 \mathrm{ft}$ apart. The fertilizers and biosolids were applied by hand to the top of each row and incorporated into the soil with a commercial bed shaper/mulch layer (Kennco Manufacturing, Ruskin, FL). Under the black polyethylene mulch, a high-flow drip irrigation tape (Aqua-Traxx; Toro, Bloomington, $\mathrm{MN}$ ) with emitters spaced every 12 inches was laid and delivered water at a rate of $0.45 \mathrm{gal} / \mathrm{min}$ for every $100 \mathrm{ft}$ of tape. Plants were irrigated twice each day for a total of $30 \mathrm{~min}$. A 10- $\mathrm{ft}$ gap within the row was provided to prevent any overlap of soil treatments and $\mathrm{N}$ movement.

After bed preparation, plugs were transplanted into the field on 22 Sept. 2015. Each fertilizer main plot was divided into four subplots containing 10 plugs each of dianthus, petunia, kale, and swiss chard planted 12 inches apart. Dianthus, petunia, and swiss chard were supplied in 288-plug trays, and kale was supplied in a 324-plug tray.

DATA COLLECTION AND ANALYSIS. Plants were grown through early December when the study was ended. Nutrient analyses were conducted on soil samples collected from each plot on 4 Nov. 2015. Soils were sampled in each plot on the date of the first whole plant sample $\{4$ Nov. [ $43 \mathrm{~d}$ after transplanting (DAT)]\} and $2 \mathrm{~d}$ after the second whole plant sample [19 Nov. (58 DAT)]. Six, l-inch-wide by 6-inch-deep cores were taken from the midpoints between two plants, $\approx 4$ inches in from the shoulder of the bed. The cores were combined and any significant plant matter was removed. Then, they were broken up, stirred, and placed in soil test boxes for air drying at room temperature. After drying, they were sent to the Mississippi State University Soil Testing
Laboratory for processing with the laboratory's standard analytical practices (Funderburg and Crouse, 1987). Response to soil amendments was measured using size index (SI), flower

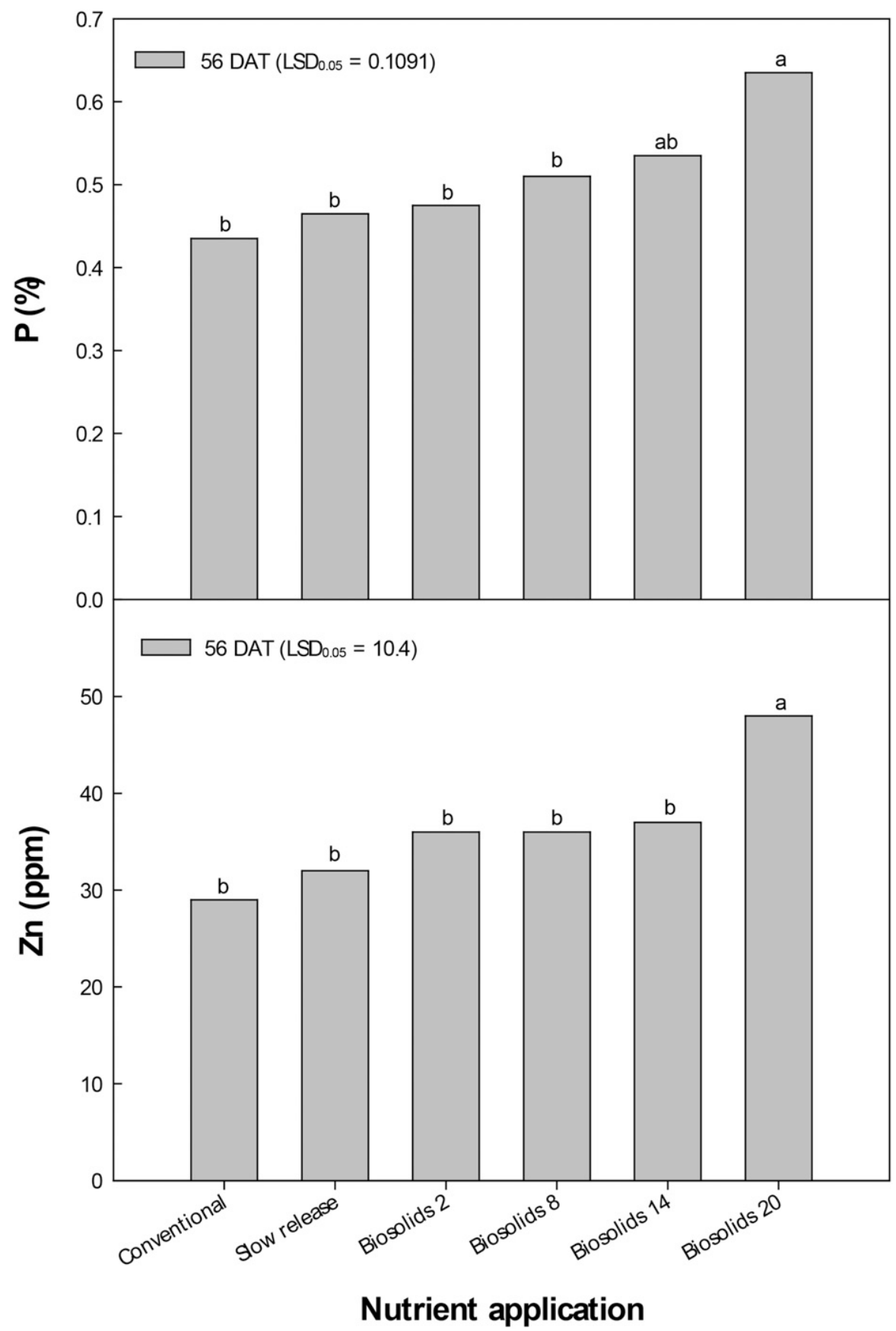

Fig. 1. Whole shoot analysis of phosphorus (P), magnesium (Mg), and zinc ( $\mathrm{Zn})$ from dianthus in response to biosolids, conventional fertilizer, and slow-release fertilizer. Samples were collected at $56 \mathrm{~d}$ after transplant (DAT). Least significant differences $\left(\mathrm{LSD}_{0.05}\right)$ are indicated in the figure legends, and bars sharing the same letters are not statistically significant. Nutrient applications included 15N-3.9P10.0K slow-release fertilizer (Osmocote ${ }^{\circledR}$; Scotts Miracle-Gro, Marysville, $\mathrm{OH}$ ) at a rate of $100 \mathrm{lb} / \mathrm{acre} \mathrm{N}(0.05 \mathrm{ton} / \mathrm{acre})$ and a conventional blend mixed to mimic the slow-release fertilizer at a ratio of 5:3:4 (N-P-K). Biosolids were added at rates of $2,8,14$, and 20 tons $/$ acre; $1 \mathrm{lb} / \mathrm{acre}=1.1209 \mathrm{~kg} \cdot \mathrm{ha}^{-1}, 1$ ton $/$ acre $=2.2417$ $\mathrm{Mg} \cdot \mathrm{ha}^{-1}, 1 \mathrm{ppm}=1 \mathrm{mg} \cdot \mathrm{kg}^{-1}$. 
count, shoot DW, and leaf nutrient analysis. The SI was measured 29 DAT and was calculated with the following equation: ( $\{[$ (longest width + perpendicular width)/2] + height $/$ / $2)$. Flower counts were recorded twice at 43 and 56 DAT. Shoots were harvested from half of the plant material and weighed after drying in an oven at $65^{\circ} \mathrm{C}$. We ground the whole shoots to pass through a 20-mesh sieve and sent ground subsamples to the Mississippi State University Extension Soil Testing Laboratory for nutrient analysis using the laboratory's standard extraction and analytical methods (Funderburg and Crouse, 1987). The data were analyzed with PROC ANOVA, PROC GLIMIX, and PROC MIXED, as appropriate, using SAS (version 9.4; SAS Institute, Cary, NC.)

\section{Results and discussion}

Biosolids ANALYsis. A sample of the biosolids revealed that $\mathrm{N}$ levels were $2.0 \%$, total $\mathrm{P}$ was $1.3 \%$, and total $\mathrm{K}$ was $0.08 \%$. Other macronutrients included calcium ( $\mathrm{Ca}$ ) at $1.3 \%, \mathrm{~S}$ at $0.37 \%$, and $\mathrm{Mg}$ at $0.13 \%$. Micronutrients consisted of $\mathrm{B}(0.0009 \%), \mathrm{Cu}$ $(0.04 \%)$, and iron $[\mathrm{Fe}(1.94 \%)]$, $\mathrm{Mn}(0.18 \%), \mathrm{Na}(0.009 \%)$ and $\mathrm{Zn}$ $(0.056 \%)$. Excessive heavy metals levels have been found in some biosolid sources (Kidd et al., 2006). If a single heavy metal exceeds USEPA limits, the biosolid cannot be land applied (USEPA, 1995). The City of Clinton sends samples of biosolids for independent testing using the toxicity characteristic leaching procedure and no $\mathrm{Cd}, \mathrm{As}, \mathrm{Cr}, \mathrm{Pb}, \mathrm{Hg}, \mathrm{Ag}$, or Se were detectable. Barium ( $\mathrm{Ba}$ ) was the only heavy metal detected, but it was more than 800-fold lower than the regulatory level. In addition, no viable human pathogens were detected. Together, these findings demonstrate that the biosolids not only meet the regulatory safety restrictions but could also be used as a soil amendment for plant or crop production.

SOIL RESPONSE TO NUTRIENT Applications. To test the efficacy of biosolids as a soil amendment, they were field applied at four rates and compared with conventional and slow-release fertilizers. Soil organic matter concentration increased with increasing rates of biosolids application. For example, at 20 tons/acre, organic matter increased to $1.42 \%$,

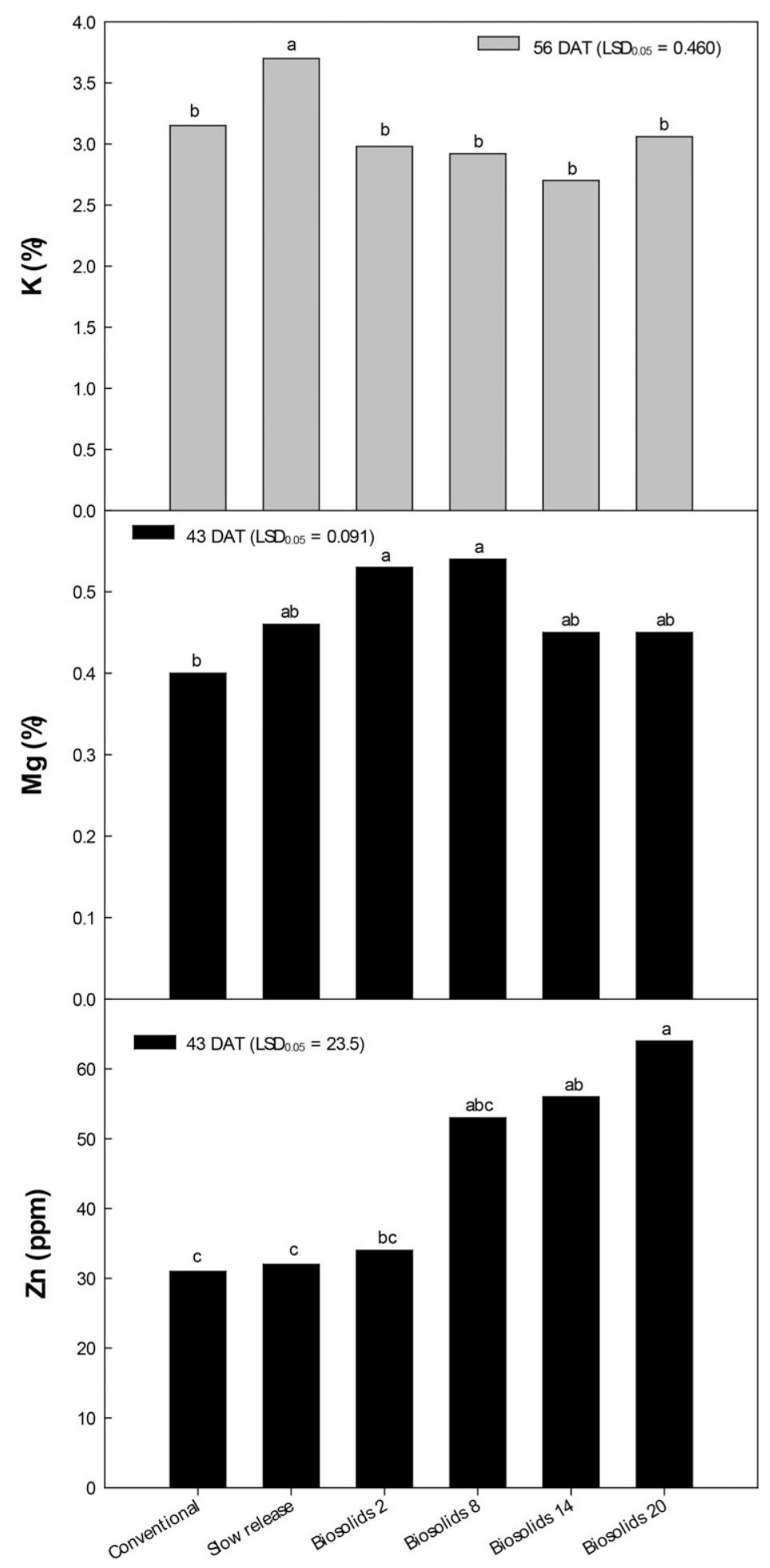

Nutrient application

Fig. 2. Whole shoot analysis of potassium (K), magnesium $(\mathrm{Mg})$, and zinc $(\mathrm{Zn})$ from kale in response to biosolids, conventional fertilizer, and slow-release fertilizer. Samples were collected at $43 \mathrm{~d}$ after transplant [DAT (black bars)] and at 56 DAT (gray bars). Least significant differences $\left(\operatorname{LSD}_{0.05}\right)$ are indicated in the figure legends, and bars sharing the same letters are not statistically significant. Nutrient applications included a $15 \mathrm{~N}-3.9 \mathrm{P}-10.0 \mathrm{~K}$ slow-release fertilizer $\left(\right.$ Osmocote $^{\circledR}$; Scotts Miracle-Gro, Marysville, $\left.\mathrm{OH}\right)$ at a rate of $100 \mathrm{lb} /$ acre N $(0.05$ ton/acre) and a conventional blend mixed to mimic the slow-release fertilizer at a ratio of 5:3:4 (N-P-K). Biosolids were added at rates of 2, 8, 14, and 20 tons/acre; $1 \mathrm{lb} /$ acre $=1.1209 \mathrm{~kg} \cdot \mathrm{ha}^{-1}, 1 \mathrm{ton} / \mathrm{acre}=2.2417 \mathrm{Mg} \cdot \mathrm{ha}^{-1}, 1 \mathrm{ppm}=1 \mathrm{mg} \cdot \mathrm{kg}^{-1}$. 


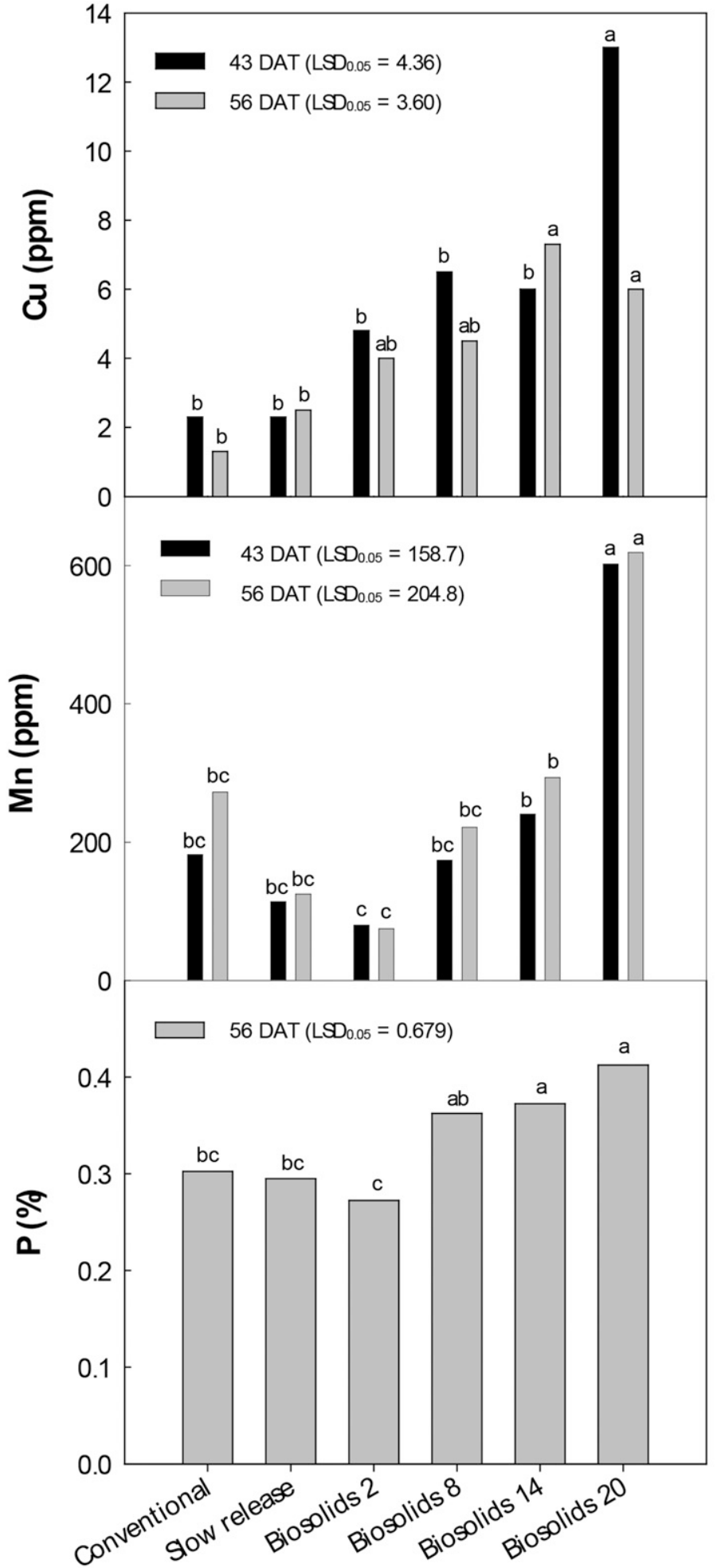

Nutrient application

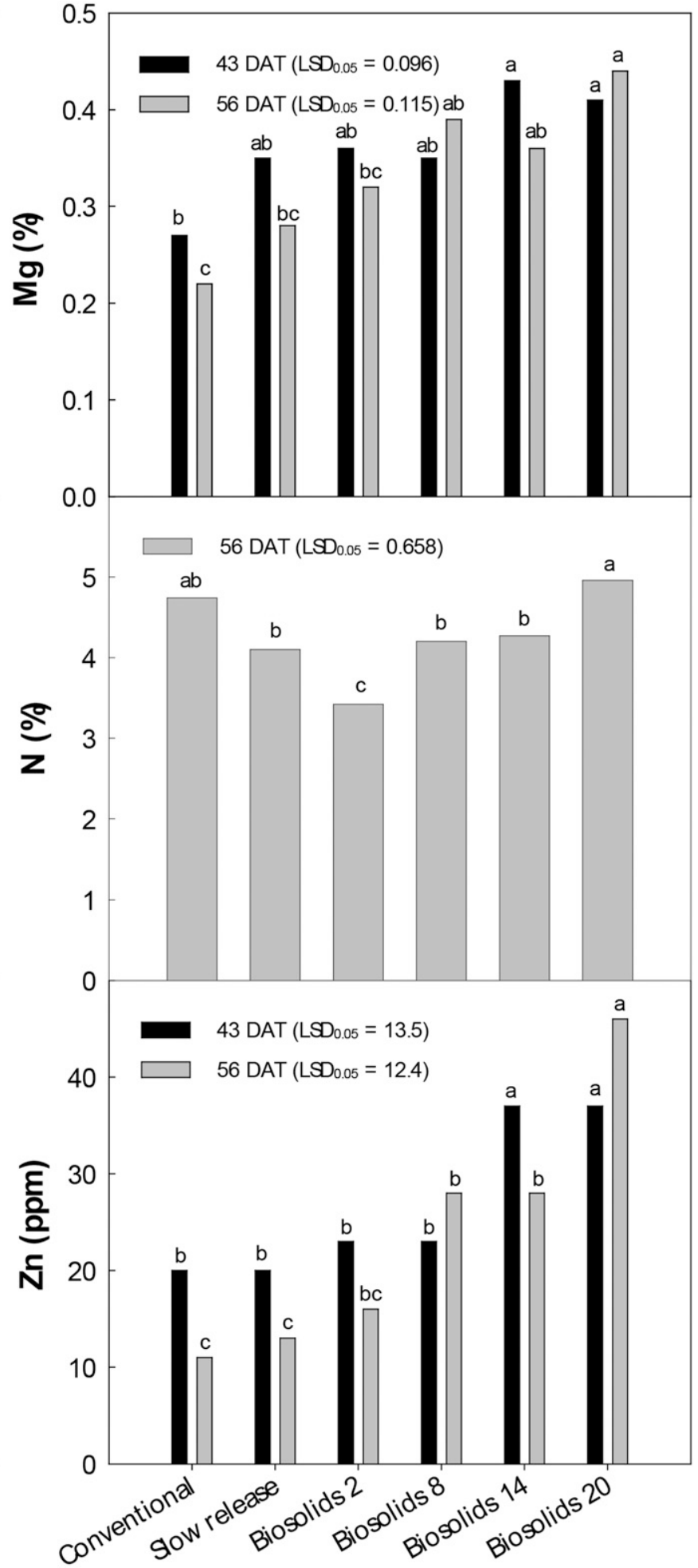

Nutrient application

Fig. 3. Whole shoot analysis of copper $(\mathrm{Cu})$, magnesium $(\mathrm{Mg})$, manganese $(\mathrm{Mn})$, nitrogen $(\mathrm{N})$, phosphorus $(\mathrm{P})$, and zinc $(\mathrm{Zn})$ from petunia in response to biosolids, conventional fertilizer, and slow-release fertilizer. Samples were collected at $43 \mathrm{~d}$ after transplant [DAT (black bars)] and at 56 DAT (gray bars). Least significant differences (LSD 0.05$)$ are indicated in the figure legends, and bars of the same color that share the same letters are not statistically significant. Nutrient applications included a $15 \mathrm{~N}-3.9 \mathrm{P}-10.0 \mathrm{~K}$ slow-release fertilizer $\left(\mathrm{Osmocote}^{\circledR}\right.$; Scotts Miracle-Gro, Marysville, OH) at a rate of $100 \mathrm{lb} / \mathrm{acre} \mathrm{N}(0.05$ ton/acre) and a conventional blend mixed to mimic the slow-release fertilizer at a ratio of 5:3:4 (N-P-K). Biosolids were added at rates of $2,8,14$, and 20 tons $/$ acre; $1 \mathrm{lb} / \mathrm{acre}=1.1209 \mathrm{~kg} \cdot \mathrm{ha}^{-1}, 1$ ton $/$ acre $=2.2417 \mathrm{Mg} \cdot \mathrm{ha}^{-1}, 1 \mathrm{ppm}=1 \mathrm{mg} \cdot \mathrm{kg}{ }^{-1}$. 
compared with $1.10 \%$ in the conventional fertilizer plots (Table 1). This increase is not a large percentage in some situations, but could have a profound effect in southeastern U.S. soils, which often have organic matter concentrations less than $1 \%$ (Overstreet and DeJong-Hughes, 2009). Organic matter is difficult to maintain in southern soils because of the warm and moist nature of the soils leading to high rates of soil oxidation (Franzluebbers, 2005; McCracken, 1959). However, a long-term study on sandy soil in Florida showed that annual applications of organic materials, including 3 years of Class B biosolids, increased organic matter, available water holding capacity, and cation exchange capacity of a sandy soil, while lowering the bulk density (Ozores-Hampton et al., 2011).

Soil $\mathrm{pH}$ was altered by the application of fertilizers, and $\mathrm{pH}$ measurements of a given treatment were higher (mean increase of 0.35 ) at the second sampling date, 58 DAT. Biosolids initially reduced soil $\mathrm{pH}$, particularly at 14 and 20 tons/acre where soil $\mathrm{pH}$ dropped below 6.0 (Table 1 ). The biosolids used for this study were acidic $(\mathrm{pH}=4.6)$, as are many organic matter sources, so the reduction in $\mathrm{pH}$ with increasing biosolids application rate was expected. Even at 20 tons/ acre, soil $\mathrm{pH}$ did not decrease to a point where lime application would be necessary. However, on soils with initially low $\mathrm{pH}$ or those with less buffering capacity than the silt loam in this study, the $\mathrm{pH}$ reduction caused by biosolids application could become problematic and would be an important management factor to consider.

Phosphorus availability was similar at 2 and 8 tons/acre to the slowrelease and conventional fertilizers, but the amount of $\mathrm{P}$ was doubled at 14 and 20 tons/acre at the first soil sampling date. At the second soil sampling date, this amount decreased to a point that was comparable with the slow-release and conventional fertilizers (Table 1). The biosolids rates added significant amounts of $\mathrm{P}$ to the system $(P<0.0001)$. The differences observed between $P$ soil tests may be due to $\mathrm{P}$ fixation in the soil, a reduction in soil $\mathrm{pH}$, or continuous soil chemical activities resulting in seasonal changes in the soil, which was occurring during this time of the year.

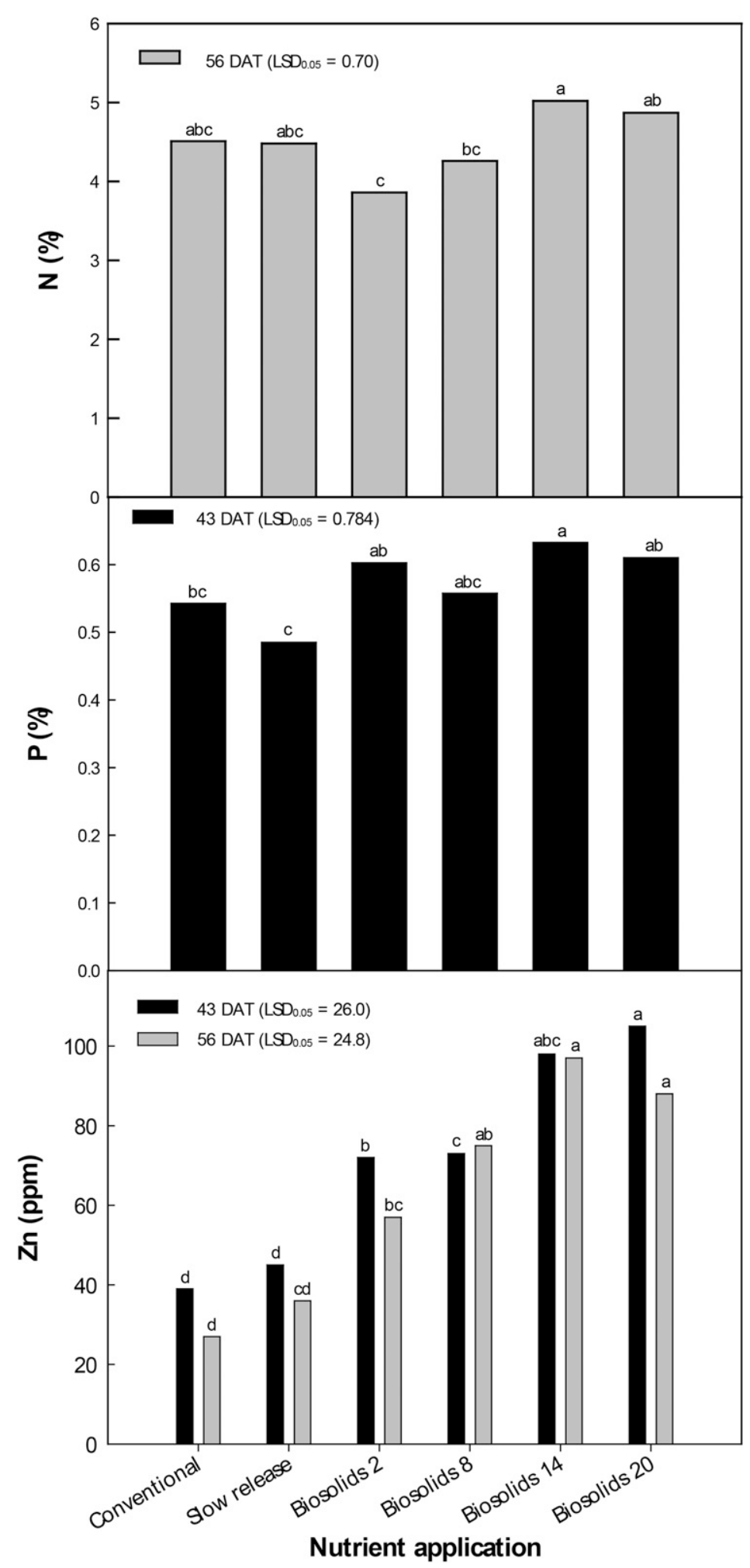

Fig. 4. Whole shoot analysis of nitrogen $(N)$, phosphorus $(P)$, and zinc $(\mathrm{Zn})$ from swiss chard in response to biosolids, conventional fertilizer, and slow-release fertilizer. Samples were collected at $43 \mathrm{~d}$ after transplant [DAT (black bars)] and at 56 DAT (gray bars). Least significant differences $\left(\right.$ LSD $\left._{0.05}\right)$ are indicated in the figure legends, and bars of the same color sharing the same letters are not statistically significant. Nutrient applications included a $15 \mathrm{~N}-3.9 \mathrm{P}-10.0 \mathrm{~K}$ slow-release fertilizer $\left(\right.$ Osmocote $^{\circledR}$; Scotts Miracle-Gro, Marysville, $\left.\mathrm{OH}\right)$ at a rate of $100 \mathrm{lb} /$ acre N $(0.05$ ton/acre) and a conventional blend mixed to mimic the slow-release fertilizer at a ratio of $5: 3: 4(\mathrm{~N}-\mathrm{P}-\mathrm{K})$. Biosolids were added at rates of $2,8,14$, and 20 tons/acre; $1 \mathrm{lb} /$ acre $=1.1209 \mathrm{~kg} \cdot \mathrm{ha}^{-1}, 1 \mathrm{ton} / \mathrm{acre}=2.2417 \mathrm{Mg} \cdot \mathrm{ha}^{-1}, 1 \mathrm{ppm}=1 \mathrm{mg} \cdot \mathrm{kg}^{-1}$. 
Biosolids application did not alter $\mathrm{K}, \mathrm{Ca}$, or $\mathrm{Mg}$ availability at either 43 or 58 DAT (data not shown). Zinc and $S$ increased as the application of biosolids increased at both 43 and 58 DAT, and while Na levels increased at 43 DAT, but this was not observed at 58 DAT (Table 1). These results are in line with most of our expectations.

Biosolids can contribute significantly to the metal content of soils, including $\mathrm{Zn}$ (USEPA, 1995). In this study, Zn levels increased with the increasing rates of biosolids application. There also appeared to be an increase in $S$ and Na levels, especially at 43 DAT (Table 1). However, none of these resulted in any adverse symptomologies in the plants. Neither $\mathrm{Zn}$, $S$, nor Na increased to toxic levels in the soil, based on several published values for preferred, marginal, and toxic or sodic levels (Espinoza et al., 2013; Marschner, 1995). The reduction observed at the second sampling date $(58$ DAT) was likely due to leaching.

Plant tissue nutrient ANALYSES. Nutrient levels in whole shoot plant tissues were measured to determine differences in nutrient uptake among the soil application treatments. Eight of the 10 elements- $\mathrm{Cu}$, $\mathrm{K}, \mathrm{Mg}, \mathrm{Mn}, \mathrm{N}, \mathrm{P}, \mathrm{S}, \mathrm{Zn}$-measured in each of the four crops had different levels in at least one of the biosolids applications from either the conventional or slow-release fertilizers (Figs. 1-4), but no differences were detected in $\mathrm{Ca}$ and Fe levels (data not shown). In dianthus grown with 20 tons/acre of biosolids, $\mathrm{P}$ levels increased by $0.2 \%$ compared with the conventional fertilizer and $0.17 \%$ compared with the slow-release fertilizer (Fig. 1). Zinc increased by $19 \mathrm{ppm}$ in dianthus grown with 20 tons/acre of biosolids compared with conventional fertilizer and $16 \mathrm{ppm}$ compared with slow-release fertilizer at 56 DAT.

In kale, $\mathrm{Zn}$ was $\approx 2$-fold higher in plants grown in 14 and 20 tons/acre of biosolids 43 DAT compared with either conventional or slow-release fertilizer (Fig. 2). At 20 tons/acre, $\mathrm{Zn}$ levels in kale were also $30 \mathrm{ppm}$ higher than kale grown with 2 tons/ acre of biosolids. Magnesium was found to be $\approx 0.13 \%$ higher in kale grown with 2 and 8 tons/acre of biosolids 43 DAT, but only when compared with conventional fertilizer.
Potassium was also found to be higher (at least $0.55 \%$ ) 56 DAT in kale grown with slow-release fertilizer than all other treatments, including the conventional fertilizer and all biosolid rates.
Petunia had the most differences in shoot nutrients (which included $\mathrm{Cu}, \mathrm{Mg}, \mathrm{Mn}, \mathrm{N}, \mathrm{P}$, and $\mathrm{Zn}$ ) of any crop (Fig. 3). At 43 DAT, Cu levels were more than 5-fold higher in petunias grown with 20 tons/acre of
A

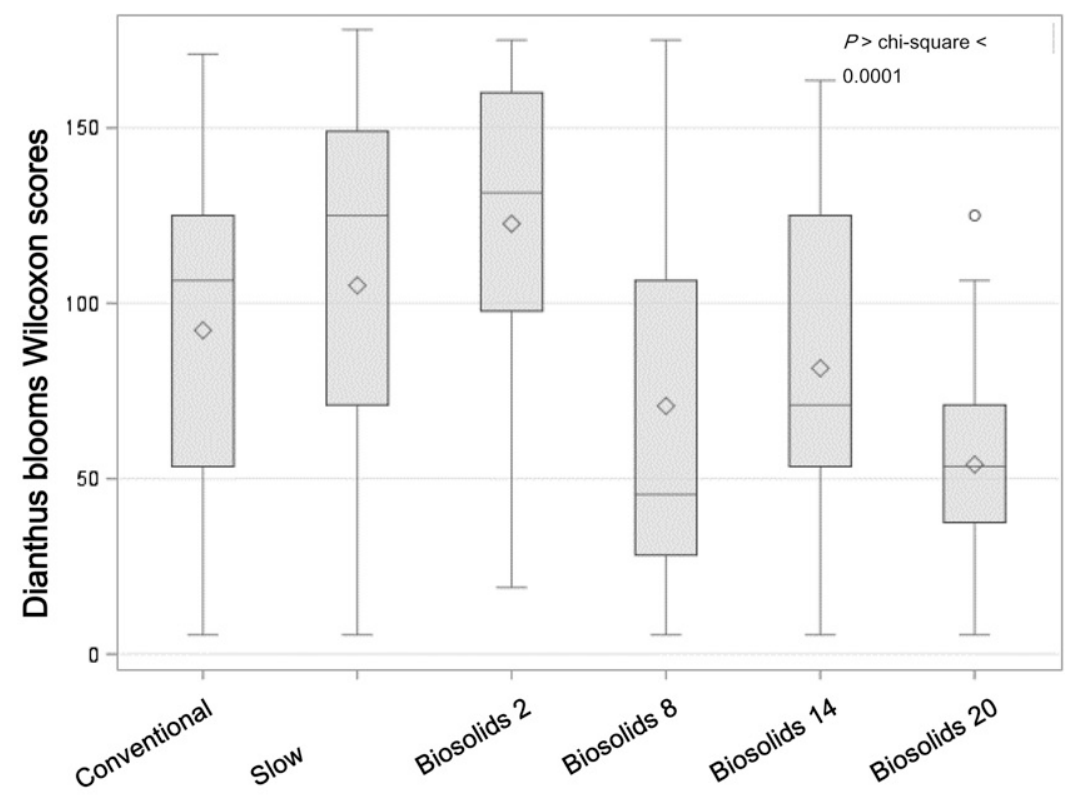

B

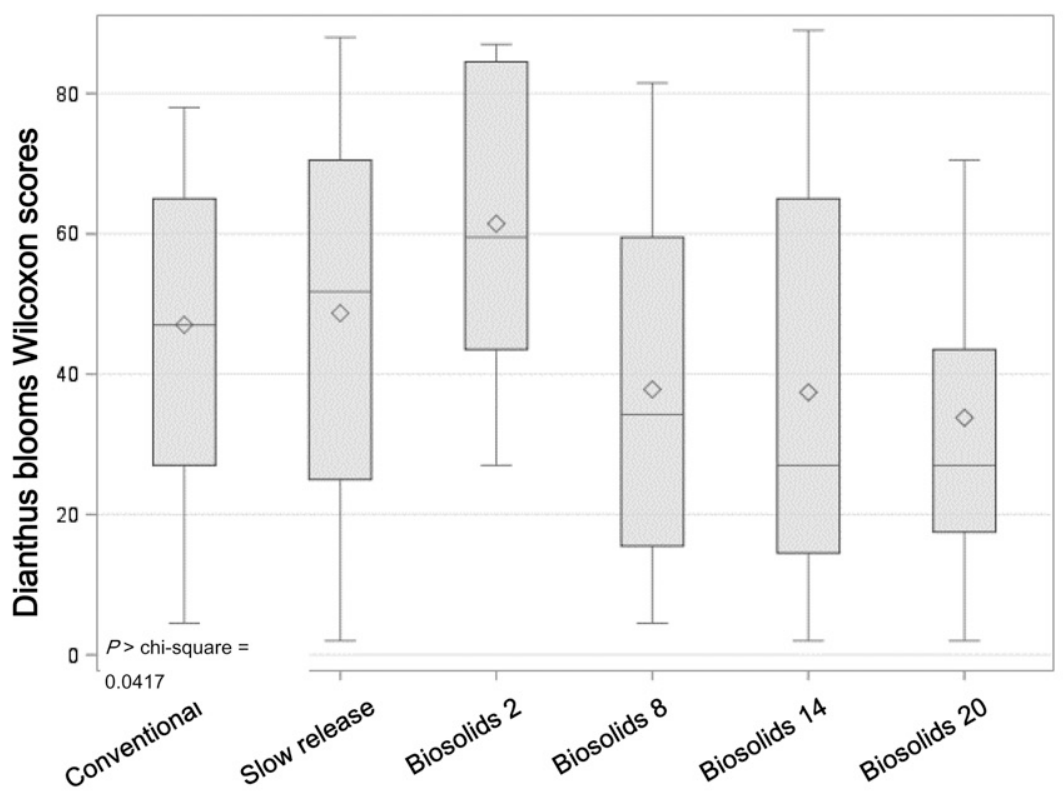

Nutrient application

Fig. 5. Flower abundance on dianthus in response to biosolids, conventional fertilizer, and slow-release fertilizer. Open flowers were counted (A) $43 \mathrm{~d}$ after transplant (DAT) and at (B) 56 DAT. Nutrient applications included a $15 \mathrm{~N}-$ 3.9P-10.0K slow-release fertilizer (Osmocote ${ }^{\circledR}$; Scotts Miracle-Gro, Marysville, $\mathrm{OH})$ at a rate of $100 \mathrm{lb} / \mathrm{acre} \mathrm{N}(0.05 \mathrm{ton} / \mathrm{acre})$ and a conventional blend mixed to mimic the slow-release fertilizer at a ratio of 5:3:4 (N-P-K). Biosolids were added at rates of $2,8,14$, and 20 tons/acre; $1 \mathrm{lb} /$ acre $=1.1209 \mathrm{~kg} \cdot \mathrm{ha}^{-1}, 1$ ton $/$ acre $=$

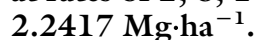


biosolids than conventional or slowrelease fertilizers, and they were around 2-fold higher than the other biosolids treatments. At 56 DAT, Cu had decreased but was still more than 2 -fold higher than petunias grown with 14 and 20 ton/acre of biosolids compared with conventional and slow-release fertilizer. At 43 and DAT, Mg was found at higher levels in petunia grown with 14 and 20 tons/acre of biosolids compared with conventional fertilizer, but not compared with slow-release fertilizer. In petunias grown with 20 tons/acre, $\mathrm{Mg}$ was found to be higher than both conventional and slow-release fertilizers and the 2-ton/acre biosolids plots, 56 DAT. At both 43 and 56 DAT, Mn levels were found to be higher (at least 2.68-fold) than both conventional and slow-release fertilizers and higher than any other biosolids treatment. A reduction in $\mathrm{N}$ of $0.68 \%$ compared with conventional fertilizer and $1.32 \%$ compared with slow-release fertilizer was detected 56 DAT in petunia at the lowest application of biosolids, 2 tons/acre. At 56 DAT, petunia had higher levels (at least $0.07 \%$ ) of $\mathrm{P}$ in 14 - and 20 -ton/ acre-treated plots than both conventional and slow-release fertilizers. Petunias grown at 2 tons/acre of biosolids had $1.4 \%$ less $\mathrm{P}$ than those grown at 20 tons/acre. At 43 DAT, $\mathrm{Zn}$ was $17 \mathrm{ppm}$ higher in petunias in the 14- and 20-ton/acre plots compared with both fertilizers and 14 ppm higher than petunias grown with 2 - and 8-ton/acre plots. At 56 DAT, $\mathrm{Zn}$ was at least $12.5 \mathrm{ppm}$ higher for 8-, 14-, and 20-ton/acre plots than either conventional or slow-release fertilizer plots.

Swiss chard had no differences in $\mathrm{N}$ when comparing biosolids plots to fertilizer plots, but the plants grown in 2 tons/acre of biosolids had $1.16 \%$ less $\mathrm{N}$ than those growing in 14 tons/ acre (Fig. 4). In addition, swiss chard growing in soils amended with 14 tons/acre of biosolids had at least $0.9 \%$ more P 43 DAT than either fertilizer treatment.

It was expected that alterations in soil nutrient levels would be reflected in the shoot nutrient levels of the plants, but this was not universally true. Changes in $\mathrm{Zn}$ and $\mathrm{P}$ were crop and time specific. In addition, the elements $\mathrm{Mg}, \mathrm{Cu}$, and $\mathrm{Mn}$ were more abundant in some of the tissue samples, but were not found at higher levels in the soils receiving biosolids. The reduction in soil $\mathrm{pH}$ that accompanied the increased biosolid application rates likely made these elements more soluble and readily absorbed by the plants. These differences in macro- and micronutrients likely contributed to some of the differences observed in plants responses.

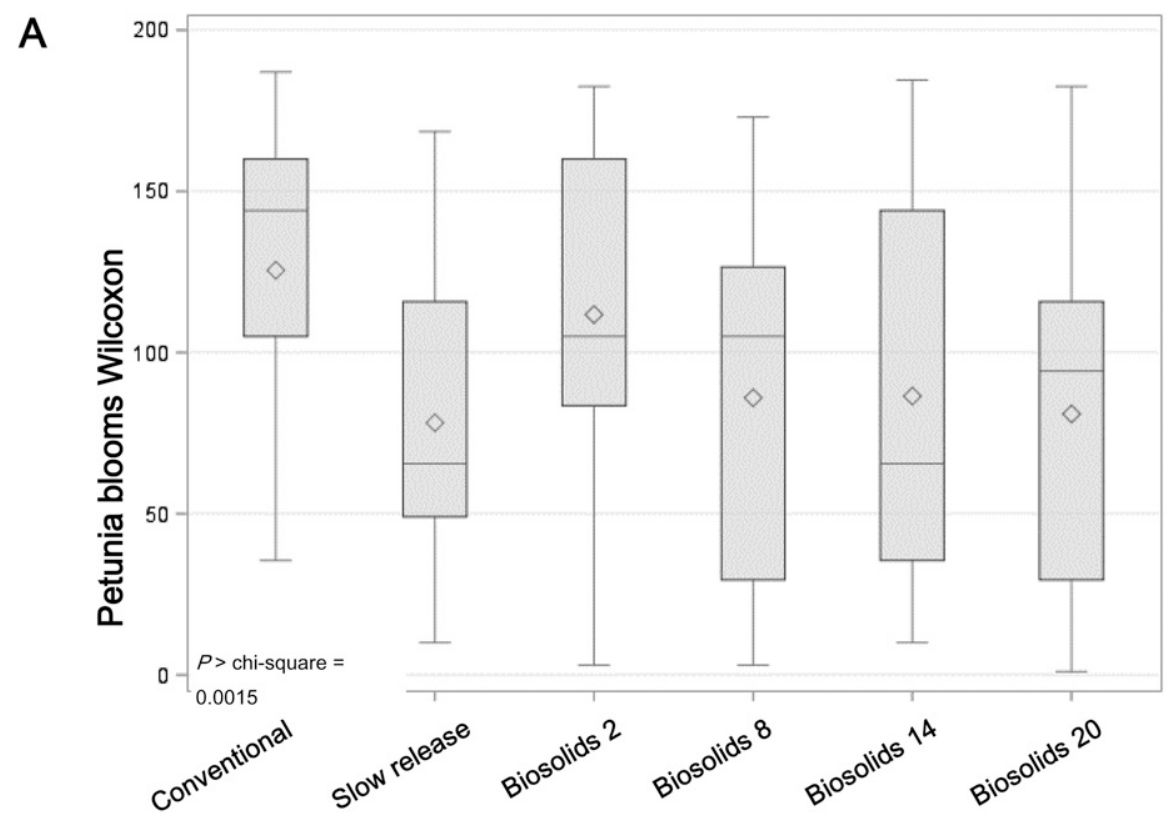

Nutrient application

B

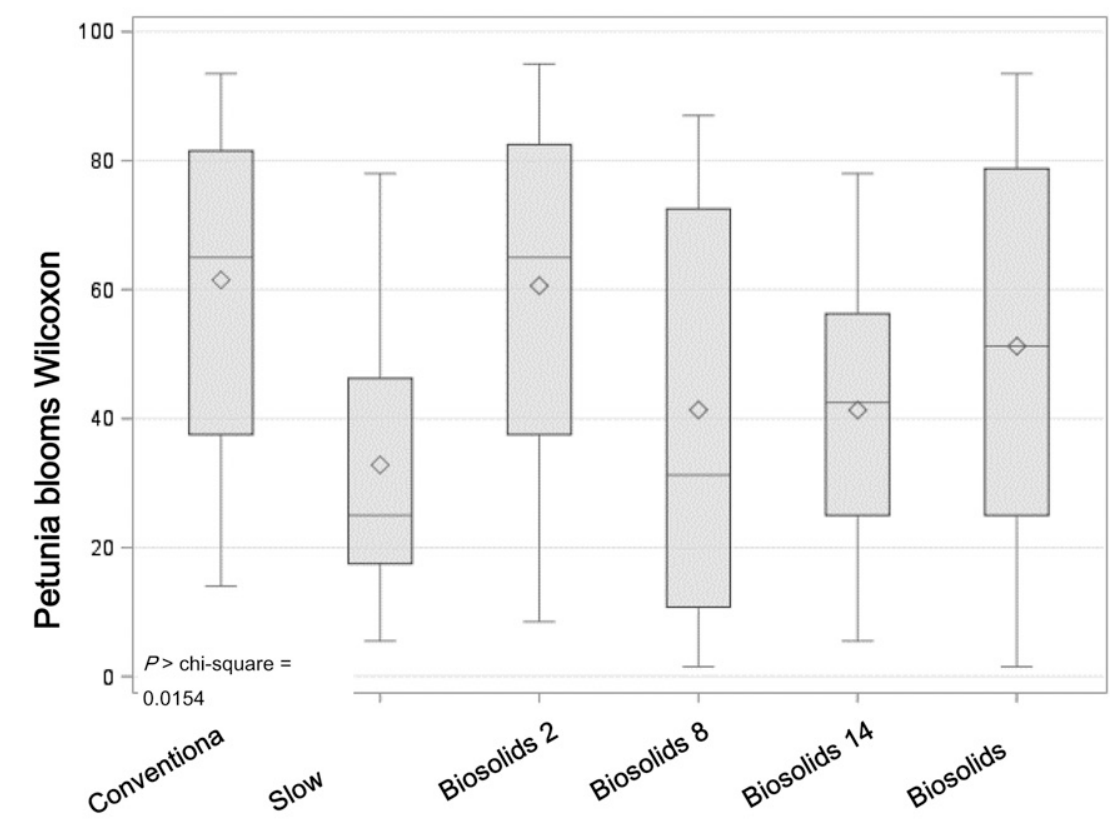

Nutrient application

Fig. 6. Flower abundance on petunia in response to biosolids, conventional fertilizer and slow-release fertilizer. Open flowers were counted (A) $43 \mathrm{~d}$ after transplant (DAT) and at (B) 56 DAT. Nutrient applications included a $15 \mathrm{~N}-$ 3.9P-10.0K slow-release fertilizer (Osmocote ${ }^{\circledR}$; Scotts Miracle-Gro, Marysville, $\mathrm{OH})$ at a rate of $100 \mathrm{lb} /$ acre $\mathrm{N}(0.05$ ton/acre $)$ and a conventional blend mixed to mimic the slow-release fertilizer at a ratio of $5: 3: 4(\mathrm{~N}-\mathrm{P}-\mathrm{K})$. Biosolids were added at rates of $2,8,14$, and 20 tons/acre; $1 \mathrm{lb} / \mathrm{acre}=1.1209 \mathrm{~kg} \cdot \mathrm{ha}^{-1}, 1 \mathrm{ton} / \mathrm{acre}=$

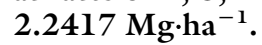


FLOWERING RESPONSE TO NUTRIENT APPLICATIONS. Flower counts varied among the different biosolid applications. Flowering was highest in both dianthus and petunia at both 43 and 56 DAT in plants growing in 2-ton/acre plots than any other biosolids application rate (Figs. 5 and 6). In petunia, these flower counts were most similar to the flower counts of the conventional fertilizer control. In dianthus, 2 -ton/acre plots promoted more flowering than both conventional and slow-release fertilizers. It is unclear why the lowest rate of biosolids promoted flowering so well. It may have been that these plants were exhibiting a stress response to reduced nutrient levels. These plants had the lowest levels of $\mathrm{Mn}, \mathrm{N}$, and P. Abiotic stresses, such as poor nutrient levels, can lead to inducing early flower development (Kolář and Seňková, 2008; Wada et al., 2010).

Plant size. To measure differences in plant size, we took SI measurements 29 DAT. No differences in SI were detected in kale across any of the treatments. In dianthus and swiss chard, however, a reduction in size at 20 tons/acre was measured. Many of these plants exhibited leaf chlorosis and were slower to establish. We hypothesize that toxic nutrient or salt levels were reached at this application rate for these crops. The SI for swiss chard was slightly reduced at the 8-ton/acre application rate (Fig. 7).

SHOOT DRY MASS ACCUMULATION. Total plant shoot growth was measured among the various fertilizer types and biosolid rates at 43 and $56 \mathrm{DAT}$. No differences in DW were observed at either collection date in dianthus, kale, or petunia. However, swiss chard had differences in DW for both collection days. At 42 DAT, swiss chard with the slow-release treatment had accumulated on average $43 \mathrm{~g}$ more DW than those given the conventional fertilizer treatment. Swiss chard averaged 20 g less DW with 8 - and 20-ton/acre biosolids application than conventional fertilizer

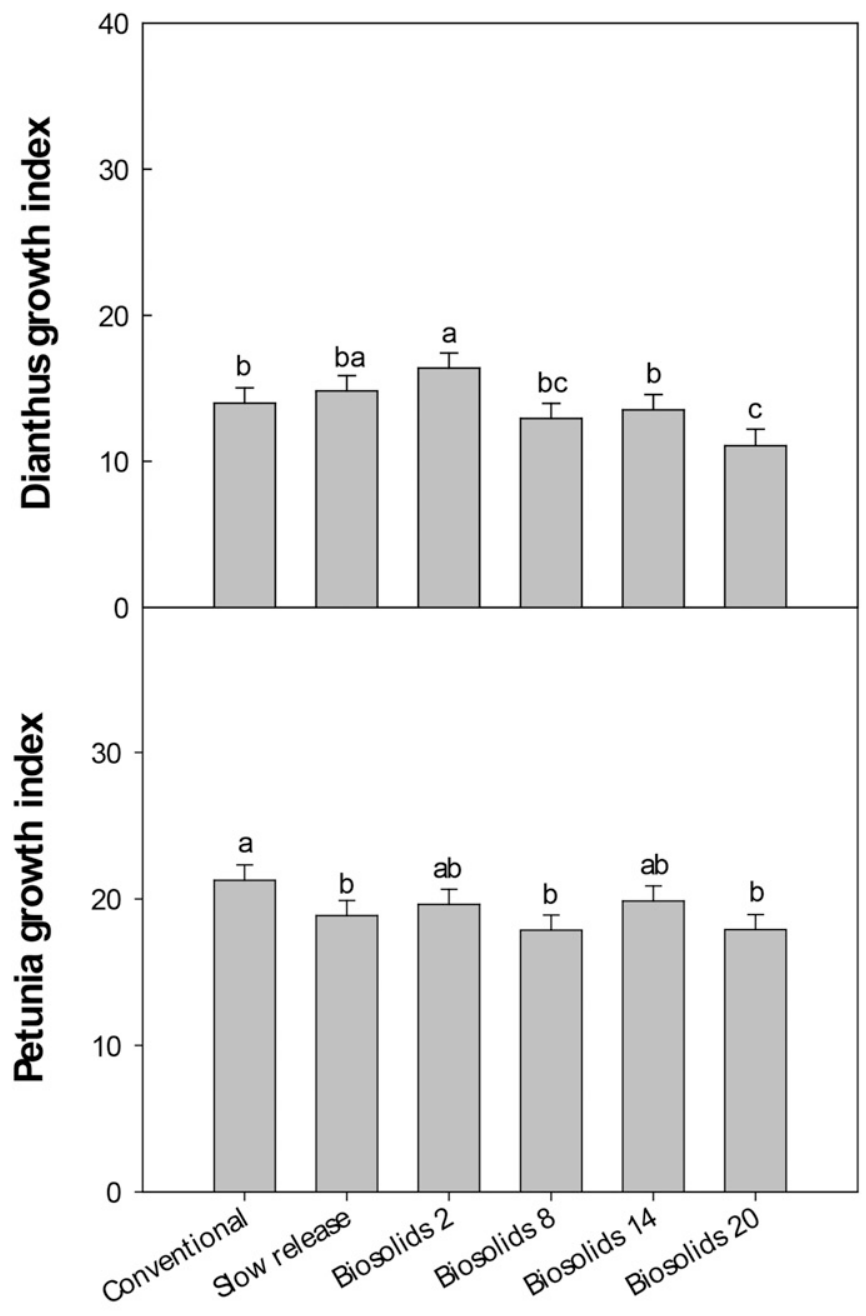

Nutrient application



Nutrient application

Fig. 7. Size indices of dianthus, kale, petunia, and swiss chard $29 \mathrm{~d}$ after transplant. Bars sharing the same letters are not statistically significant. Nutrient applications included a $15 \mathrm{~N}-3.9 \mathrm{P}-10.0 \mathrm{~K}$ slow-release fertilizer (Osmocote ${ }^{\circledR}$; Scotts MiracleGro, Marysville, $\mathrm{OH})$ at a rate of $100 \mathrm{lb} / \mathrm{acre} \mathrm{N}(0.05 \mathrm{ton} / \mathrm{acre})$ and a conventional blend mixed to mimic the slow-release fertilizer at a ratio of 5:3:4 (N-P-K). Biosolids were added at rates of $2,8,14$, and 20 tons/acre. The size index was calculated using $(\{[($ longest width + perpendicular width $) / 2]+$ height $\} / 2) ; 1 \mathrm{lb} / \mathrm{acre}=1.1209 \mathrm{~kg} \cdot \mathrm{ha}^{-1}, 1 \mathrm{ton} / \mathrm{acre}=2.2417 \mathrm{Mg} \cdot \mathrm{ha}{ }^{-1}$. 
(Fig. 8). At 56 DAT, plants grown in the conventional and slow-release fertilizers were comparable in weight, and the 2 - and 8 -ton/acre application rates were reduced (Fig. 8). This variability in the swiss chard may be attributable to the variability of the plugs. These plugs were generated from a swiss chard seed mix containing different colors of swiss chard with variable growth habits. The similarity of the size of the three crops suggests that plant response is on par with conventional and slow-release fertilizers. Therefore, farmers would likely be able to achieve comparable yield from biosolids as they would from conventional fertilizer methods.

\section{Conclusion}

This research demonstrates the usefulness of biosolids in replacing conventional $\mathrm{N}$ sources while supplying other nutrients and organic matter. Our data demonstrate the efficacy of using biosolids as an alternative nutrient source to conventional and slow-release fertilizers. While rates of 2, 8 , and 14 tons/acre did not appear to cause toxicity, the highest level of biosolids applied, 20 tons/acre, did cause phytotoxicity particularly at the early growth stage. Repeated applications of biosolids to soils would likely increase organic matter in the soils, improve soil structure, decrease soil density, and improve water-holding capacity. Using Grade A, EQ biosolids in agricultural settings can be a sustainable method of recycling municipal water waste in a way that helps sustain crop production. Their increased adoption into horticultural and other agricultural settings will reduce our reliance on synthetic fertilizer sources, reduce greenhouse gas emissions, and improve the

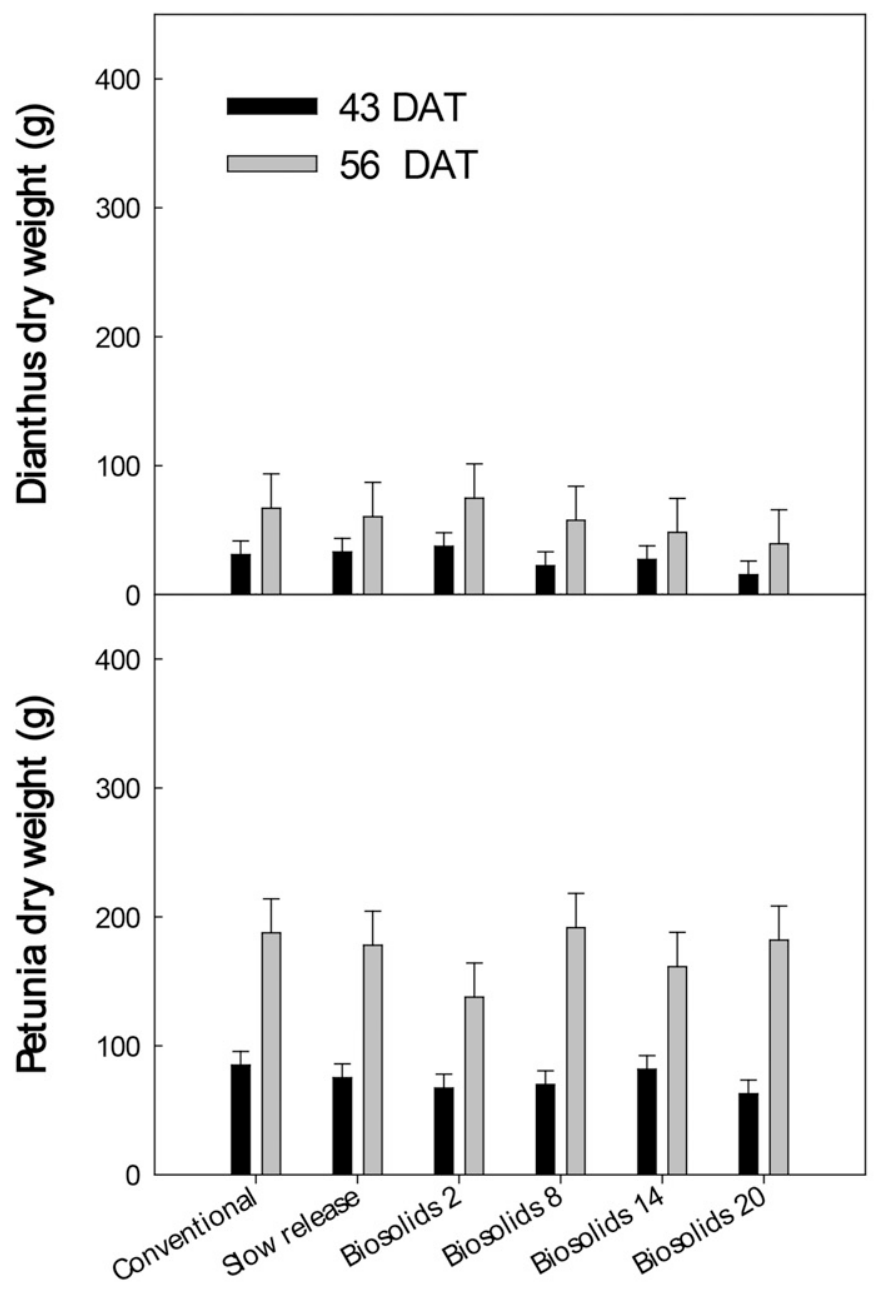

Nutrient application

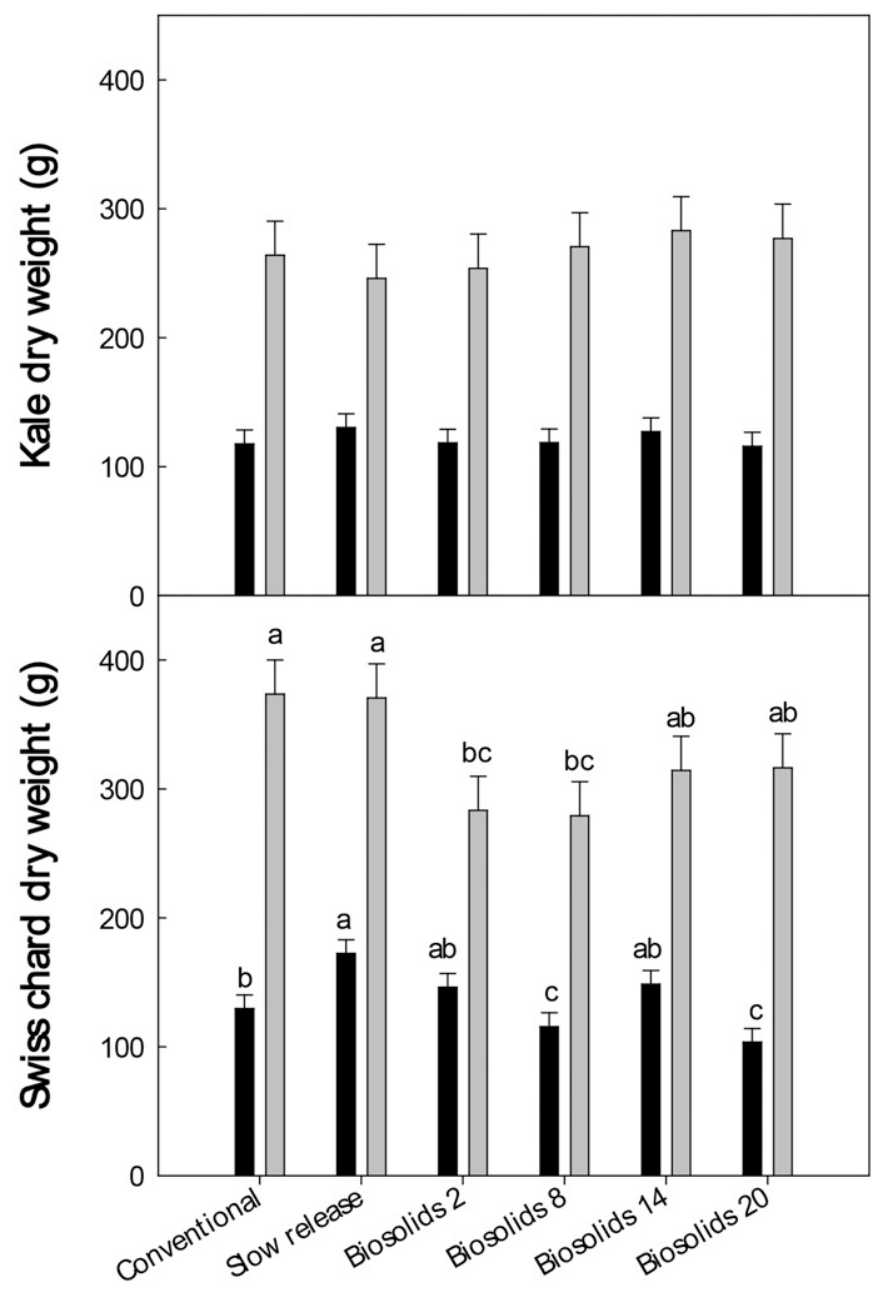

Nutrient application

Fig. 8. Shoot dry weight accumulation in dianthus, kale, petunia, and swiss chard in response to biosolids, conventional fertilizer, and slow-release fertilizer. Half of the plants within each subplot were harvested at $43 \mathrm{~d}$ after transplant [DAT (black bars)] and the other half was harvested at 56 DAT (grey bars). Bars of the same color sharing the same letters are not statistically significant. Nutrient applications included a $15 \mathrm{~N}-3.9 \mathrm{P}-10.0 \mathrm{~K}$ slow-release fertilizer $\left(\right.$ Osmocote ${ }^{\circledR}$; Scotts MiracleGro, Marysville, $\mathrm{OH})$ at a rate of $100 \mathrm{lb} / \mathrm{acre} \mathrm{N}(0.05 \mathrm{ton} / \mathrm{acre})$ and a conventional blend mixed to mimic the slow-release fertilizer at a ratio of 5:3:4 (N-P-K). Biosolids were added at rates of $2,8,14$, and 20 tons/acre. The size index was calculated using $(\{[($ longest width + perpendicular width $) / 2]+$ height $\} / 2) ; 1 \mathrm{lb} / \mathrm{acre}=1.1209 \mathrm{~kg} \cdot \mathrm{ha}^{-1}, 1 \mathrm{ton} / \mathrm{acre}=2.2417 \mathrm{Mg} \cdot \mathrm{ha}^{-1}$, $1 \mathrm{~g}=\mathbf{0 . 0 3 5 3} \mathrm{oz}$. 
sustainability of municipal and agricultural ecosystems.

\section{Literature cited}

Espinoza, L., N.A. Slaton, and M. Mozaffari. 2013. Understanding the numbers on your soil test report. Univ. Arkansas Dept. Agr. Coop. Ext. Serv. FSA2118PD112RV.

Franzluebbers, A.J. 2005. Soil organic carbon sequestration and agricultural greenhouse gas emissions in the southeastern USA. Soil Tillage Res. 83:120147.

Funderburg, E. and K.K. Crouse. 1987. Procedures used by the Mississippi soil testing and plant analysis laboratory. Mississippi State Univ. Ext., Mississippi State University, Starkville, MS.

Kidd, P.S., M.J. Domínquez-Rodríquez, J. Díez, and C. Monterroso. 2006. Bioavailability and plant accumulation of heavy metals and phosphorus in agricultural soils amended by long-term application of sewage sludge. Chemosphere 66:1458-1467.

Kolář, J. and J. Seňková. 2008. Reduction of mineral nutrient availability accelerates flowering of Arabidopsis thatiana. J. Plant Physiol. 165:1601-1609.
Lu, Q., Z.L. He, and P.J. Stoffella. 2012. Land application of biosolids in the USA: A review. Appl. Environ. Soil Sci. 2012:1-11.

Marschner, H. 1995. Mineral nutrition of higher plants. 2nd ed. Academic Press, London, UK.

McCracken, R.J. 1959. Certain properties of selected southeastern United States soils and mineralogical procedures for their study. Virginia Agr. Expt. Sta. Southern Regional Bul. 61.

National Research Council. 2002. Biosolids applied to land: Advancing standards and practices. Natl. Acad. Press, Washington, DC.

North East Biosolids and Residuals Association. 2007. A national biosolids regulation, quality, end use and disposal survey: Final report. North East Biosolids Assn., Tamworth, NH.

Overstreet, L.F. and J. DeJong-Hughes. 2009. The importance of soil organic matter in cropping systems of the northern Great Plains. 28 Sept. 2017. <http:// www.extension.umn.edu/agriculture/ soils/soil-properties/importance-of-soilorganic-matter $/>$.

Ozores-Hampton, M., P.A. Stansly, and T.P. Salame. 2011. Soil chemical, physi$\mathrm{cal}$, and biological properties of a sandy soil subjected to long-term organic amendments. J. Sustain. Agr. 55:245-259.
Sharpley, A.N., S.C. Chapra, R. Wedepohl, J.T. Sims, T.C. Daniel, and K.R. Reddy. 1993. Managing agricultural phosphorus for protection of surface waters: Issues and options. J. Environ. Qual. 23:437-451.

Tubail, K., L. Chen, F.C. Michel, Jr., H.M. Keener, J.F. Rigot, M. Klingman, D. Kost, and W.A. Dick. 2008. Gypsum additions reduce ammonia nitrogen losses during composting of dairy manure and biosolids. Compost Sci. Util. 16:285-293.

U.S. Environmental Protection Agency. 1979. A history of land application as a treatment alternative. U.S. Environ. Protection Agency Publ. MCD-40.

U.S. Environmental Protection Agency. 1995. Guide to the biosolids risk assessments for the EPA Part 503 Rule. U.S. Environ. Protection Agency Publ. EPA/ 832-B93-005.

Wada, K.C., M. Yamada, T. Shiraya, and K. Takeno. 2010. Salicylic acid and the flowering gene FLOWERING LOCUS T homolog are involved in poor-nutrition stress-induced flowering of Pharbitis nil. J. Plant Physiol. 167:447-452.

Warman, P. and W. Termeer. 2005. Evaluation of sewage sludge, septic waste and sludge compost applications to corn and forage: Yields and N, P and $\mathrm{K}$ content of crops and soils. Bioresour. Technol. 96:955-961. 